\title{
Immune titers of protection against severe acute respiratory syndrome coronavirus 2: are we there yet?
}

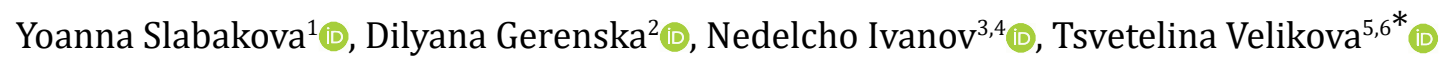 \\ ${ }^{1}$ Medical University-Sofia; Blvd. "Akademik Ivan Evstratiev Geshov" 15, 1431 Sofia, Bulgaria \\ ${ }^{2}$ Department of Pharmacovigilance, Blvd. "Tsarigradsko shoes" 115G, 1784 Sofia, Bulgaria \\ ${ }^{3}$ Department of Clinical Immunology, University Hospital Alexandrovska, Sveti Georgi Sofiyski 1, 1431 Sofia, Bulgaria \\ ${ }^{4}$ Medical University-Sofia, Sofia, Bulgaria \\ ${ }^{5}$ Department of Clinical Immunology, University Hospital Lozenetz, Kozyak 1 str, 1407 Sofia, Bulgaria \\ ${ }^{6}$ Sofia University St. Kliment Ohridski, Sofia, Bulgaria
}

*Correspondence: Tsvetelina Velikova, Department of Clinical Immunology, University Hospital Lozenetz, Kozyak 1 str, 1407 Sofia, Bulgaria; Sofia University St. Kliment Ohridski, Sofia, Bulgaria. tsvelikova@medfac.mu-sofia.bg

Academic Editor: Wangxue Chen, National Research Council Canada, Canada

Received: September 3, 2021 Accepted: January 4, 2022 Published: February 11, 2022

Cite this article: Slabakova Y, Gerenska D, Ivanov N, Velikova T. Immune titers of protection against severe acute respiratory syndrome coronavirus 2: are we there yet? Explor Immunol. 2022;2:9-24. https://doi.org/10.37349/ei.2022.00033

\begin{abstract}
A few pieces of research exist about the protective titer against severe acute respiratory syndrome (SARS) coronavirus 2 (CoV-2; SARS-CoV-2) in monkeys and humans in which the protection could be shown as dose-dependent. Early studies supposed that higher levels of pre-existing neutralizing antibodies (Nabs) against SARS-CoV-2 can potentially correlate with the protection to consequent infection. The data so far showed that cellular immunity is as essential as the humoral one. If needed, its presence can be beneficial if the titer of immunoglobulins is not optimal. It is also known that the immune response to the vaccine is similar to the one after natural infection with a production of very high naturalization titers antibodies. However, medical community is still unaware of the immunoglobulin titer needed for protection against the virus. The answers to the questions regarding correlates of protection are yet to be discovered. Still, no studies indicate a specific virus-Nab titer, so one can assume a patient is protected from being infected in the future. The evoked immunological response is indeed encouraging, but a future investigation is needed. Nonetheless, it remains a mystery how long the immunity lasts and whether it will be enough to shield the patients in the long run. Therefore, identifying immune protection correlations, including neutralization titer of antibodies and $\mathrm{T}$ cell immune response against SARS-CoV-2, could give a clue. Unfortunately, recent studies in the field have been more controversial than concise, and the data available is far from consensus.
\end{abstract}

\section{Keywords}

Severe acute respiratory syndrome coronavirus 2, coronavirus disease 2019, antibodies, correlates of protection, immunoglobulin titers, B cells, T cells 


\section{Introduction}

The ongoing global coronavirus disease 2019 (COVID-19) pandemic caused by the severe acute respiratory syndrome (SARS) coronavirus 2 (CoV-2; SARS-CoV-2) has already taken the lives of 5 million people and infected more than 255 million people worldwide [1]. Nevertheless, unfortunately, so far, no one has taken responsibility to pinpoint a specific protective titer of antibodies against SARS-CoV-2 in humans [2]. However, there have been a few papers about the protective titer against SARS-CoV-2 in monkeys (Macaca mulatta) in which the protection is dose-dependent. The study showed that cellular immunity is as essential as the humoral one. If needed, its presence can be beneficial if the titer of immunoglobulins is not optimal [3].

From vaccine trials in 2020 , we know that the immune response to the vaccine is similar to the one after natural infection with very high naturalization titers. However, we are still unaware of the immunoglobulin titer needed for protection against the virus. The evoked immunological response is indeed encouraging, but a future investigation is needed [4]. Furthermore, recent articles noted that the correlates of protection are yet to be discovered [5]. Still, no studies indicate a certain virus-neutralizing antibodies (Nabs) titer, so we can assume a patient is protected from being infected in the future. Nonetheless, it remains a mystery how long the immunity lasts and whether it will be enough to shield the patients in the long run [5].

Coronaviruses are one of the leading causes of infections in the animal kingdom. Seven of them are known to affect humans. The CoV family has a lot of similarities between the members. All of them are enveloped RNA viruses and have spikes (S) on their surface. Four out of the seven are the main reason for the so-called "common cold" infections: human CoV 229E (HCoV-229E), HCoV-OC43, HCoV-NL63, and HCoV-HKU1 [6]. They are regularly seen $(15 \%)$ in the pediatric and adult populations. Severe disease can be caused by other family members like Middle East respiratory syndrome CoV (MERS-CoV), SARS-CoV, and the current SARS-CoV-2, leading to pneumonia, severe complications, and death [6].

A systematic review of Huang etal. [7] focused on public-health interventions and COVID-19 model epidemic scenarios induced by SARS-CoV-2, presuming that the infection leads to an immune response that provides a specific period of protection against subsequent infections or diseases. However, infections and/or vaccinations may impact future transmission and disease severity or may not be protective immunity (if available). The authors reviewed the available scientific literature on CoV antibody immunity, including SARS-CoV-2 and associated SARS-CoV, MERS-CoV, and human endemic CoVs. They examined 2,452 abstracts and 491 handbooks and concluded that a correlation of protection needs to be identified before the known exposure or risk period in which infection or disease outcome is defined [7]. Generally, most long-term investigations have shown that SARS-CoV and MERS-CoV immunoglobulin G (IgG) has decreased with time (usually up to one year). In contrast, others have demonstrated measurable amounts of $\operatorname{IgG} 3$ years after the infection. In addition, the intensity gradient of antibodies varied in kinetics, and more severe symptoms stayed evident after sickness [7].

Furthermore, the challenges of humans with $\mathrm{HCoV}$ demonstrate the probable correlated protective effects against infection and diseases in the serum and mucosal immune responses (serum IgG, IgA, Nabs titer and mucosal IgA) [7]. However, a repeated challenge with a single $\mathrm{HCoV}$ in human trials shows that people may get $\mathrm{HCoV} 1$ year after the initial challenge, although it may be less severe. Cross-reactivity between alpha and beta CoVs is also possible. While endemic HCoVs seldom generate the cross-reaction of antibodies against emerging HCoVs, SARS-CoV and MERS-CoV activate pre-HCoV-induced antibodies [7].

We have to be aware that variants of concern (VOC) may reduce the efficacy of Nabs in both convalescents and vaccinated people [8]. For example, B.1.1.7 (alpha) reduced neutralization titer by 2.9 times, B.1.351 (beta)-13.3 times, and B.1.617.2 (delta) 2.6 times. Furthermore, reducing neutralization titers above 8 times leads to a 50\% decrease in protection threshold by day 90 following COVID-19 [9]. Thus, it would be possible to predict the duration of protection after a previous SARS-CoV-2 infection. However, this hypothesis should be validated further.

Lau et al. [8] suggested that even protection by Nabs against the specific variant that caused the infection (especially after symptomatic disease) is likely to remain for almost 2 years [8]. However, VOC may disrupt this protection and make the individual susceptible to all new variants [10]. 
Identifying correlates of immune protection, including neutralization titer of antibodies and $\mathrm{T}$ cell immune response against SARS-CoV-2, is urgently needed. However, recent studies in the field have been more controversial than concise, and the data available is far from consensus.

\section{Lessons for protective titer antibodies against other SARS-CoV}

When we discuss the correlate titers of protection, we have to start with the existing knowledge on other CoVs. A 2004 study proved that IgG antibodies were still found in the patients' blood 60 days following SARS-CoV infection. In contrast, IgM levels dropped quickly and were not detectable after 77 days [11]. This research showed a significant drop (at least 5 times) in immunoglobulin titers in 9 months. In addition, asymptomatic patients seemed to have a lesser immune response to the virus, and their antibodies disappeared even faster [10]. Previous studies also found that antibodies against the S1 S protein have a virus-neutralizing effect by blocking the binding to receptors [12].

However, research regarding protective immunity was needed for vaccine development, so an animal model was used. Mice were injected with receptor-binding domain (RBD)-fragment crystallizable region (Fc) of immunoglobulin and boosted consecutively at different periods. The humoral response was explored, extending to a year after immunization. During the study, the mice were rechallenged with the same strain of SARS-CoV. It was found that RBD can be used in the making of subunit vaccines because of the robust protective humoral immunity it provokes [13].

A prospective cohort study with healthcare workers (HCWs) showed that people infected in 2003 demonstrated detectable IgG to CoVs 12 years later [14]. Moreover, the highest immunoglobulin titer was assessed in 2004. During the infection, the ones treated with corticosteroid drugs had lesser humoral response, and the IgG levels were lower. The study concluded that the existence of IgG antibodies against SARS-CoV could protect the survivors from re-infection with the primary or other beta CoVs as well [14].

Another study, while researching nidoviruses and the immunogenicity of SARS-CoV in mice and rabbits, showed potent inhibition of SARS-CoV after immunization with RBD-Fc protein [15]. The observed mean 50\%-neutralization titers in antisera were estimated as 1:15,360 [15]. Another remarkable demonstration from the same study was that the titers of antibodies against the S protein needed for $50 \%$ inhibition after immunization were 1:7,393 and 1:2,060 in rabbits and mice, respectively [15].

Studies have implied possible immune cross-reactivity between SARS and betacoronavirus HCoV-EMC closely related to other zoonotic CoVs in Hong Kong. Around $2 \%$ of the tested individuals had antibody titer against the virus and SARS-CoV $\geq 1: 20$. The neutralizing immunoglobulins were $<1: 10$. The researchers detected that $60 \%$ of SARS survivors had detectable antibody titers, and $25 \%$ had a low HCoV-EMC titer with neutralizing activity [16]. However, further investigation proved that there is no cross-neutralization between the two viruses [17].

Another study performed in the UK proved the variability of neutralizing humoral response in participants. However, most antibodies persisted for a few months after infection [18]. In the first week after infection, all of the patients were negative for Nabs. However, the following week $64 \%$ of the participants tested positive. The mean titers were up to 40 . Ranging from 1 to 200, all of the patients were positive in week 3. The highest titers were detected in week 4, with an inhibitory concentration of 90 and a mean titer from 28 to 640. In some patients, the humoral immunity endured for more than 200 days after initial symptoms [18].

Several monoclonal antibodies were isolated while searching for a cure during the SARS-CoV epidemic; they had virus-neutralizing activity. However, their concentrations peaked 2 months post-infection; the neutralizing immunoglobulins, on the other hand, remained at a stable concentration (1/128). All of them were IgG1 isotypes [19].

Research made by Gao et al. [20] that showed a robust immune response in monkeys following intramuscular immunization with the adenoviral vector vaccine was crucial for a vaccine against SARS development. Another animal model that used ferrets and chimpanzees examined and proved that 
adenoviral vaccines evoke a specific and safe immunity needed to protect and prevent pneumonia after being challenged with SARS-CoV and stimulated robust immune responses in macaques [21].

The humoral immune response to SARS-CoV was studied in a 2006 prospective study that took 2 years in China [22]. The serum samples were analyzed with enzyme-linked immunosorbent assay (ELISA), and the titers of neutralizing immunoglobulins were estimated by neutralization assays. Sixty-three participants satisfied the criteria and were included in the survey, and 56 of those gave 3 blood samples. The ones with comorbidities were 9, and 27 were male. Five of them were treated with prednisolone during the illness [22]. IgG was found in all follow-up visits except the last one (11.8\% negative results). The maximum titer was assessed at the 4th month (mean IgG reciprocal titer 250). A massive decrease was noted after one year. Nabs were investigated and tested positive in all visits. Again, a peak was evidenced 4 months post-infection (mean Nabs reciprocal titer estimated between 1,000-1,500). Interestingly, sex seems to play an essential role in the duration of humoral response because the decline of immunoglobulins was more rapid in the male participants. Again, there was not a certain titer pointed as protective [22].

Rockx et al. [23] published a paper on monoclonal antibody cross-resistance between mutant strains of SARS-CoV. They demonstrated that the amino acid sequence is crucial for antibody activity, making immune escape impossible [23]. Therefore, when we try to pinpoint the protective titer against SARS-CoV-2, we should consider the type of antibody most effective for neutralizing other variants. Although escape mutants were a problem researched by Rockx et al. [23], in his article, it was noted that monoclonal antibodies were effective in protecting mice from heterologous SARS-CoV variants.

In 2012 there was another CoV outbreak-MERS-CoV, another zoonotic infection that came from camels and was the reason for the death of more than 800 patients in its first appearance in Saudi Arabia [24]. It spread in 27 countries. According to the World Health Organization (WHO), the mortality rate was 35\%. In a study conducted with three groups of patients with mild, moderate, and severe MERS infection made in Saudi Arabia 6 years after infection, the serology results showed a correlation between the severity of the disease and the titer of virus-neutralizing titer (VNT) [24]. The median titer of VNT in the tested patients was 45 in the second year, 76 in the fourth, and 42 in the sixth year after infection, respectively. Six years after infection, VNT was detected in $100 \%$ of moderate and severe cases and $50 \%$ in mild cases [24].

A more recent study with rhesus macaques regarding vaccines against MERS found the protectivetiter 14 days after the vaccine [25]. Neither group was infected with MERS beforehand, and no immunoglobulins were present before vaccination. Thus, the vaccine not only decreased the severity of the disease significantly but limited the virus replication as well. Although the study was not meant to discover the correlates of protection, interestingly enough, it was mentioned that one of the animals was protected despite not having detectable antibodies [25]. Similarly, a clinical study including MERS survivors was carried out in 2017. A few of the patients did not have any detectable immunoglobulins. However, they had a robust CD8 ${ }^{+}$ T-cell response [26].

Callow et al. [27] researched common cold CoVs with low severity. They were able to test the humoral immunity in a group of volunteers. The research team published in the Journal of Hygiene in 1985 demonstrated that IgA was associated with less virus shedding, reduction of symptoms, and protection against re-infection. The local secretory immunoglobulins were high for a few weeks after infection. Interestingly enough, there was proof that a more recent infection meant that the volunteers were less susceptible to the virus. They had little to no symptoms, and the viral shedding period was shortened [27].

HCoVs with low severity have been used in human studies over the years, measuring the antibody response after infection and the protection they guaranteed. An article published in Cambridge University Press displayed volunteers' immune response to common cold CoV 229E [28]. Although there was still antibody titer detectable one year after infection, re-infections with the same virus occurred. The virus shedding period was shorter, and some resistance was noted. In 3 weeks after inoculation, the immunoglobulins raised significantly. Unfortunately, by the 12th week, the concentration decreased strikingly. The immune response showed individuality and divergence. Most of the volunteers' titers (especially IgG) returned to normal 1 year later. During the rechallenge, the volunteers from the uninfected 
group became infected. Furthermore, the majority of participants from the infected group were re-infected but did not progress to a cold. In both groups, the duration of virus shedding was shorter [28].

\section{Searching for protective titer antibodies against SARS-CoV-2}

Article published in 2021 indicated that perhaps the immunity after infection with SARS-CoV-2 is not as short-lived as we believed [29]. Although there was a decrease in immunoglobulins post-infection, plasmatic cells were found in aspirates of bone marrow in 15 of the 19 volunteers who had the infection prior. Furthermore, the antibody responses were tested in 77 patients, from whom the blood samples were consecutively taken at first, the fourth, the seventh, and eleventh month and showed a decline in anti-S IgG antibodies (from 6.3 to 5.3 mean $\log _{\mathrm{e}}$-transformed half-maximal dilution) but were still detectable [29]. That decline correlated and depended on the conversion of plasma cells residing in the bone marrow. The plasmablasts (reliant on T-cells) detected in the early stages of recovery secrete antibodies that decline rapidly. However, a more stable titer is observed once they convert into long-lived plasmatic cells in the bone marrow. This study implies that the persistence of antibodies is not the only line of protection. Except for the noted bone marrow plasma cells (BMPCs), there are B-memory cells that quickly adapt in the presence of antigen and are fundamental factors in the long-lasting immune defense against SARS-CoV-2 [29].

From April to June 2020, a study was conducted in the UK. It involved 78 medical practitioners who previously suffered from COVID-19. Exceedingly inconsistent immune response was observed among the volunteers, especially regarding the $\mathrm{T}$ cell response and $\mathrm{N}$-specific antibodies. However, their humoral immunity grouped them into two groups-high and low responders (who produce antibodies). The study implied that protection from re-infection with different strains might be possible [30].

\section{Dynamics of antibodies during infection with SARS-CoV-2}

Humoral immunity seems to be a key player in the immune arsenal of protection against SARS-CoV-2. Its main targets are the $S$ protein and the internal nucleocapsid antigen. Okba et al. [31] report that in a most polymerase chain reaction (PCR)-confirmed SARS-CoV-2 cases, seroconversion is observed around two weeks after disease onset.

Additionally, a complex multiparametric study by Zohar et al. [32] describes a plethora of exciting associations of antibody specificities, subclasses, and $\mathrm{Fc}$ receptor ( $\mathrm{FCR}$ ) binding profiles and the disease outcome. According to the study comparing humoral immune response in different categories of patients (moderate, severe, and patients who eventually died due to COVID-19), IgM and IgA evolved similarly and were a common finding. However, a proper IgG response was observed only in the survivors' group, which, authors hypothesized, was probably due to appropriate FcR function utilization [32].

The dynamics of immune responses during infection with SARS-CoV-2, similar to vaccine challenge, are presented in Figure 1.

Nevertheless, significant heterogeneity was observed in patients who survived the infection, including both fast IgG-converters and individuals who converted to IgG slowly but steadily. Other curious findings with the potential for being correlates of protection were steady IgG1 class-switching and early S2-specific antibody elevation [33]. While Nabs are the main factor of protection from subsequent re-infection, antibodies specific for S and RBD with other functionalities such as antibody-dependent complement deposition (ADCD) and antibody-dependent cellular phagocytosis (ADCP) and other Fc-dependent functions seem to play a critical role in viral clearance itself after the infection has already been established [33]. Thus, we can argue that some antibodies (e.g., neutralizing) are protective per se and defend us from subsequent re-infection with SARS-CoV-2 while others are, but more precisely, curative. Their titers may be crucial for the current disease outcome (e.g., antibodies with primary Fc-dependent functions).

On the other hand, autoantibodies with certain specificities generated during the infection (anti-type I interferon antibodies) are rendered as pathogenic or aggravating [33]. Zhu etal. [34] proposed that the kinetics of immune response should be measured to decide on vaccination. However, the official medical consensus on this topic is different. 


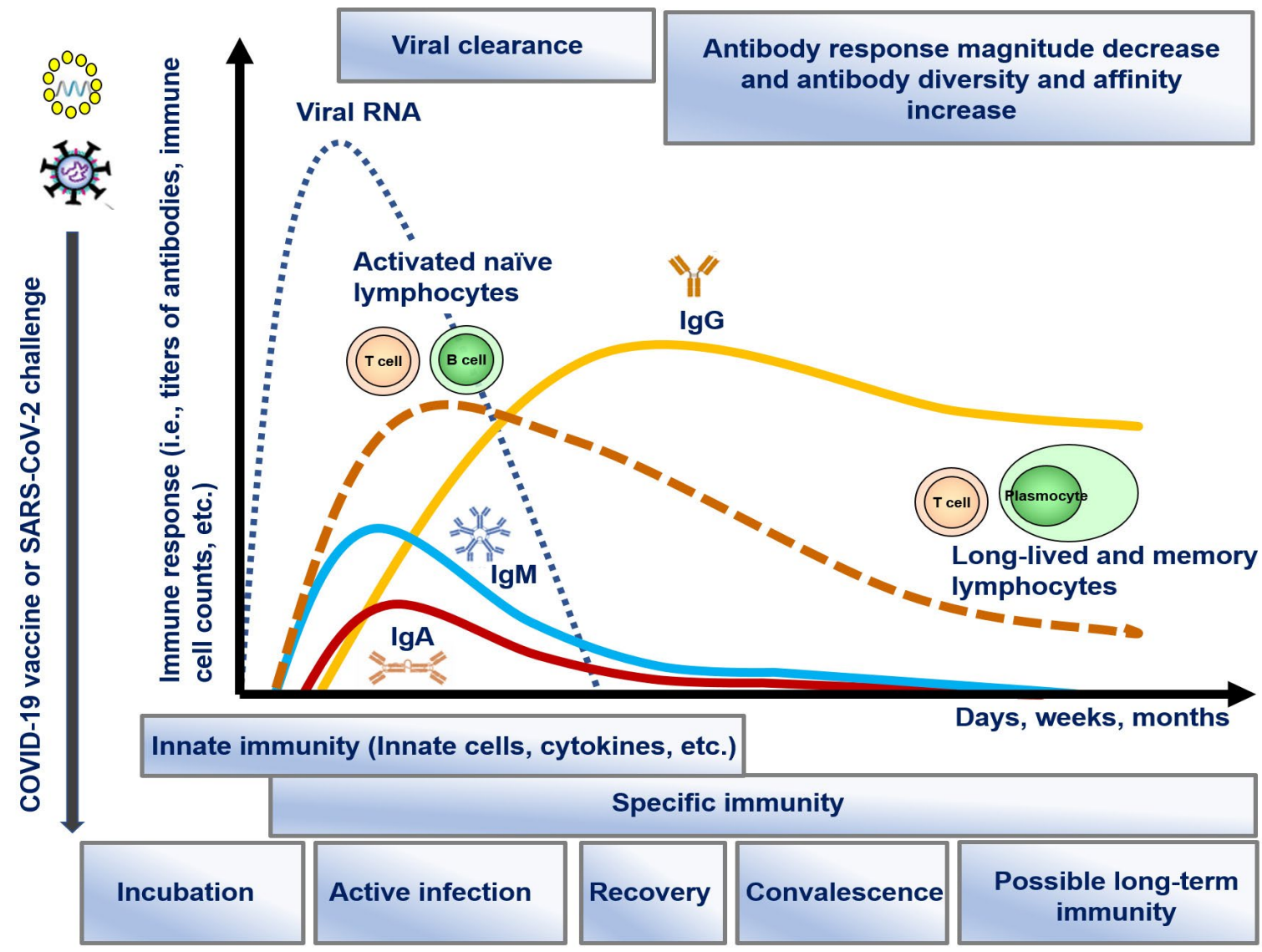

Figure 1. Dynamics of immune response development after encountering SARS-CoV-2, including innate immunity involvement and specific (adaptive) immune mechanisms (activation of T and B cells and production of antibodies), leading to viral clearance possible development of long-lived and memory lymphocytes together with matured and more affinity and diverse antibodies in the post-infection and convalescent period. The same immune response is activated after vaccination (on the figure-RNA vaccine), without the infection periods and viral load in the organism

Furthermore, S2 is the most conserved part of the S-protein, and antibodies to S2 seem to be cross-reactive with other beta CoVs [35]. RBD- and S2-specific FcyR2B and FcyR3B binding antibodies started to elevate steadily from the first week of infection in the severe survivors' group. In contrast, in the individuals whose infection ultimately ended up fatal, their titers were low and elevated poorly. Thus, pre-existing cross-reactive immunity to $\mathrm{S} 2$ seems to facilitate the initial viral control, has a positive predictive value [33], and maybe a good strategy for utilization in future pan- $\beta$-CoV vaccines [36].

A study regarding protection against symptomatic disease (with B.1.177 and B.1.1.7 variants) after vaccination showed a correlation between serological assay and infection [37]. However, significant variability between participants was noted. The likelihood of infection was lower in patients with a more robust antibody response, but it was absent. This study mentioned a similar correlation in respiratory syncytial viru (RSV), once again emphasizing that categorical titer is still unknown [37].

European Centre for Disease Prevention and Control (ECDC) states that antibody titer is evidential for some protection, but it's still unknown how long the immunity will last and whether the protection is sufficient for prevention for future infection. We also fully support ECDC's statement that the presence of antibodies accounts for some protection. However, it is still unknown how long the immunity is going to last and whether or not the titer is sufficient for preventing future SARS-CoV-2 infections [38].

The dynamic in antibody titer after natural infection with SARS-CoV-2 was examined in Wuhan, China, one year after symptoms. Although the highest titer was found 3-4 months after disease onset (above 1:160), there was a slow decline up to the 6th month. Thus, after one year, the Nabs titers were low and unable to counteract the beta variant [39].

That is why amplifying the natural immunity with a single dose can be beneficial for previously infected individuals. However, for the pandemic to stop, we need an unsusceptible population worldwide. If the previous statement is not fulfilled, the prognosis will continue to be pessimistic. 


\section{Dynamics of antibodies after vaccination against SARS-CoV-2}

The wide distribution of different types of vaccines around the globe is a crucial step towards ending the SARS-CoV-2 pandemic on an international level. As the number of vaccines administered rises, more data becomes available regarding their safety, efficacy, and tolerability among humans [40, 41].

However, correlates of protection after immunization with SARS-CoV-2 vaccines are yet to be clarified [41]. Recently published research about correlates of protection against SARS-CoV-2 in rhesus macaques provides information about the antibodies' levels (including virus-Nabs) and the correlation with protection against SARS-CoV-2 [3, 42]. It indicates that relatively low levels of antibodies are required for defense in the upper and low respiratory tracts. The titers of Nab, which are found to be effective in protecting against SARS-CoV-2, are also considered to be reasonably low. Cellular immunity might play an important role when the level of antibodies starts to decline [42]. Therefore, the licensed vaccines against SARS-CoV-2 must stimulate sufficient humoral and cellular immune responses [43].

Vaccines based on two major technologies are the ones currently in most accelerated use. AZD1222 (AstraZeneca) uses a non-replicant chimpanzee adenoviral vector (ChAdOx1), encoding and transports the S-protein [44]. Data about the immune response in the vaccine recipients (during phase $1 / 2$ clinical trial in the UK) show that anti-S IgG antibodies are detected 28 days after the first dose. It is additionally estimated that antibodies titers rise after the second dose. Evidently, Nab is found in $91 \%$ of the vaccinees after prime dose and in $100 \%$ of them after the boost immunization [41].

Correlates of protection were investigated while researching vector vaccine-Ad26.COV2.S, after immunization and infected later on with SARS-CoV-2, lung tissue was collected 4 days later. Antibody titer and VNT titer were measured. The hamsters before inoculation and were randomized to two groups-infected and noninfected. Viral load beneath $10^{2}$ tissue culture infectious dose (TCID50)/g was established as a sign of preventing disease. Interestingly enough, the protected group had antibody binding titers above 3.5 using ELISA and virus-Nabs above 64. Perhaps animal models could shed some light on the matter with protective titer [45].

Tostanoski et al. [46] team researched the susceptibility for SARS-CoV-2 in hamsters as well. About 50 Syrian golden hamsters were previously immunized with vector vaccine. The challenge was made in week 4 after vaccination. The ELISA titer at week 2 correlated with the viral load oppositely (negatively) with the virus found in lung tissue on the 4th day after exposition [46].

The efficacy of current vaccines was researched, and antibody titers were shown to be predictive of immunity. Geometric IgG mean titers using ELISA corresponded with the antibodies found in vaccinated individuals after 1 to 4 weeks following immunization. The highest efficacy was correlating with titersabove $1 \times 10^{4}$ binding antibody units (BAU/mL). Geometric mean titers of Nab corresponded with over $95 \%$ vaccine efficacy. A titer above 400 was associated with high efficacy, although the effectiveness remained high with even lower antibody titer [47]. Perhaps not everything is as black and white as we hoped for.

The behavior of SARS-CoV-2 immunity was predicted in analysis using data from 7 vaccine studies and one regarding convalescent patients. The prediction was that although the neutralization declined over time and booster doses were needed, the protection from severe infection lasted longer than expected. Furthermore, the highest vaccine protective efficacy corresponded with mean neutralization titer above 4 [10].

An article published in the Journal of Infection showed an intriguing correlation between antibody titer and the possibility of future infection in more than 8,758 HCWs with a median age of 40 and over 50\% females [48]. The study was conducted in France starting in July of 2020 and finishing in April 2021. When the authors analyzed the data, they speculate that we should have in mind the epidemic conditions in the county itself in the same timeframe. The study itself did not examine T-cell immunity [48]. The methods used were ELISA and assay in Vero cell with the B.1.160 strain for neutralization titers. A significant advantage in this study was the use of BAU/mL as an international standard unit. This study shows that having Nab above 256 and total antibody measured with ELISA above $1,700 \mathrm{BAU} / \mathrm{mL}$ predicted $100 \%$ protection against future SARS-CoV-2 infection [48]. However, among the limitations of this study was the lack of data for disease 
progression in the HCWs with positive tests and how that correlated with the previously existing antibody titer. Perhaps routine antibody screening might be helpful for addressing the need for boosting immunity.

Another vector-based vaccine, Ad26.COV2.S (Janssen), is administered as a single dose. Results from the placebo-controlled 1/2a trial indicate that Nabs against SARS-CoV-2 are found in $90 \%$ of vaccinees on day 29 and in $100 \%$ of them on the 57 th day. There is a strong correlation between the quantity of the S-binding antibodies and the Nab. This is mainly observed in the younger vaccine recipients [41].

The RNA vaccines consist of lipid nanoparticle nucleoside-modified mRNAs that encode and deliver the SARS-CoV-2 S protein to the cell. Following the first dose, I of BNT162b2 (BioNTech/Pfizer) binding IgG antibodies against the $S$ protein are detected. It is noticeable that virus-Nabs are found in most vaccine recipients on day 28, seven days after the second administration [41]. Moderna's vaccine (mRNA1273) demonstrated immunization after the first dose. The booster dose led to rising quantities of both binding and $\mathrm{Nab}$ in all vaccinees during the phase 1 clinical trial [41].

Additionally, one dose of either mRNA vaccine in previously infected with SARS-CoV-2 leads to a prompt immune response. The antibody titers following vaccination are almost the same or even higher than those who are seronegative and received a complete vaccination cycle. This finding should be a subject of further research [43].

The Nab titer post-vaccination is related to the vaccine's protection efficacy. Considering that, Nab could be labeled as an immune correlate of protection. However, additional binding and functional antibodies also might have a part in the protection process [49-51]. Considering the data, further investigation regarding the protective titers of antibodies against SARS-CoV-2 and their dynamics is required.

Khoury et al. [10] reported on data from currently vaccinated people to analyze the association of in vitro neutralization level with the observable protection SARS-CoV-2 infection [10]. They calculated the neutralization threshold to be $20.2 \%$ of average convalescent $[95 \%$ confidence interval (CI) $=14.4 \%$ to $28.4 \%$ ], at $50 \%$ protection against detectable SARS-CoV-2 infection. The estimated level of neutralization necessary to protect against severe infection was substantially lower (3\% of average recovery level; $95 \%$ $\mathrm{CI}=0.7-13 \%, P=0.0004$ ] [10]. Modeling of the degradation in the titer of neutralization in the first 250 days after vaccination indicates that the protection from SARS-CoV-2 infection will be significantly decreased while it is important to maintain protection against severe conditions. Neutralization titers for certain variations of SARS-CoV-2 are lowered in relation to the vaccination strain, and our model predicts the link between neutralization and viral variant effectiveness. Here, the authors show that the neutralization level of immune protection is highly predictive and presents an evidentiary model of immune protection against SARS-CoV-2 that helps establish vaccination policies to monitor a future trajectory [10].

Dimeglio et al. [48] also show that immunization increases the immune response of infected HCWs. The most remarkable conclusion is that those HCWs immunized 9-12 months following their SARS-CoV-2 first illness were not re-infected. The rate for infected but unvaccinated HCWs is in favorable contrast.

This is possible owing to the extraordinarily high quantities of Nabs seen in individuals vaccinated with one or two doses. Thus, excellent protection against SARS-CoV-2 re-infection seems to be available in persons who have been infected and vaccinated [48]. However, there were no data of Nab titers in vaccinated HCW but not previously infected. The results now indicated that the Nab titers of the infected persons were lower than those that were infected and vaccinated. However, they found no difference in Nabs and re-infection rates between those HCWs infected before July 2020, who got a single dose of vaccination and HCWs with two doses. This supports the recent advice to administer a single dose of the vaccination to patients who are already infected with SARS-CoV-2, even if the illness is "old" (over 9 months) [48]. Finally, the authors found that antibodies that attach and neutralize $S$ protein continue to present up to a year after infection. Furthermore, their findings show that vaccination for those already sick generates a high level of protection considerably higher than that after infection alone. This is very significant for HCWs that stay exposed to SARS-CoV-2 more than most people [48]. 
However, at this point of gained knowledge, there is still a debate on the differences and durability of natural versus vaccine-induced antibodies, including their correlates titer of protection [52].

A summary of existing data on the correlates titer of protection is presented in Table 1.

Table 1. Correlates titer of protection against SARS-CoV-2 proposed by different study groups

\begin{tabular}{|c|c|c|c|c|c|}
\hline $\begin{array}{l}\text { Authors, } \\
\text { reference }\end{array}$ & $\begin{array}{l}\text { Type of } \\
\text { study }\end{array}$ & Design & $\begin{array}{l}\text { Subjects, } \\
\text { participants }\end{array}$ & $\begin{array}{l}\text { Methods for anti-SARS-CoV-2 } \\
\text { antibodies detection, units }\end{array}$ & $\begin{array}{l}\text { Proposed correlate titer of } \\
\text { protection (units) }\end{array}$ \\
\hline $\begin{array}{l}\text { Corbett } \\
\text { et al. [53] }\end{array}$ & Animal model & $\begin{array}{l}\text { mRNA-1273 } \\
\text { vaccine }\end{array}$ & $\begin{array}{l}\text { Non-human } \\
\text { primates }\end{array}$ & $\mathrm{IU} / \mathrm{mL}$ & $\begin{array}{l}\text { No animal with S-specific } \\
\text { IgG }>336 \mathrm{IU} / \mathrm{mL} \text { had BAL } \\
\text { subgenomic RNA (sgRNA) > } \\
10,000 \text { copies/mL, and no } \\
\text { animal with S-specific IgG > } \\
645 \mathrm{IU} / \mathrm{mL} \text { had NS sgRNA > } \\
100,000 \text { copies/swab, so these } \\
\text { were chosen as the thresholds } \\
\text { for protection }\end{array}$ \\
\hline \multirow{9}{*}{$\begin{array}{l}\text { Sui et al. } \\
\text { [50] }\end{array}$} & \multirow[t]{9}{*}{ Animal model } & Vaccine & \multirow{9}{*}{$\begin{array}{l}\text { Non-human } \\
\text { primates }\end{array}$} & \multirow[t]{9}{*}{ Ab-pseudo/live Nab } & \multirow{9}{*}{$\begin{array}{l}10-160 / N / A \\
408 / 113 \\
1862 / 3481 \\
\text { N/A/200 } \\
\text { N/A/10-100 } \\
\text { N/A/74 }\end{array}$} \\
\hline & & ChAdOx1 & & & \\
\hline & & nCov-19 & & & \\
\hline & & Ad26 & & & \\
\hline & & Cov2.S & & & \\
\hline & & mRNA-1273 & & & \\
\hline & & BBIBP-CorV & & & \\
\hline & & PiCovacc & & & \\
\hline & & DNA & & & \\
\hline \multirow[t]{4}{*}{$\begin{array}{l}\text { Feng et al. } \\
\text { [37] }\end{array}$} & \multirow[t]{4}{*}{$\begin{array}{l}\text { Randomized } \\
\text { single-blind } \\
\text { vaccine } \\
\text { efficacy trial }\end{array}$} & \multirow[t]{4}{*}{$\begin{array}{l}\text { ChAdOx1 } \\
\text { nCoV-19 } \\
\text { vaccine }\end{array}$} & \multirow[t]{4}{*}{ Humans } & $\begin{array}{l}\text { For } 90 \% \text { VE: anti-S IgG: } 899 \\
\text { (369, NC), BAU/mL; Anti-RBD } \\
\text { IgG: } 2360 \text { (723, NC) BAU/mL } \\
\text { Normalized live-virus }\end{array}$ & \multirow{4}{*}{$\begin{array}{l}\text { For } 80 \% \text { VE against primary } \\
\text { symptomatic COVID-19, for } \\
\text { anti-S IgG, was a level of } \\
264 \mathrm{BAU} / \mathrm{mL} \\
\text { For anti-RBD IgG, } 80 \% \text { efficacy } \\
\text { was achieved with a median } \\
\text { antibody level of } 506 \mathrm{BAU} / \mathrm{mL} \\
(95 \% \mathrm{Cl}: 135, \mathrm{NC})\end{array}$} \\
\hline & & & & $\begin{array}{l}\text { neutralization assay: } 938 \text { ( } 294 \text {, } \\
\text { NC) } \mathrm{NF}_{50}\end{array}$ & \\
\hline & & & & $\begin{array}{l}\text { Pseudovirus neutralization } \\
\text { assay: } 140(43, \mathrm{NC}) \mathrm{IU} / \mathrm{mL}\end{array}$ & \\
\hline & & & & $\begin{array}{l}\text { A vaccine efficacy of } 80 \% \\
\text { against symptomatic infection } \\
\text { with majority alpha (B.1.1.7) } \\
\text { variant of SARS-CoV-2 was } \\
\text { achieved with } 264 \mathrm{BAU} / \mathrm{mL} \text { : } \\
\text { and } 506 \mathrm{BAU} / \mathrm{mL} \text { for anti-S } \\
\text { and anti-RBD antibodies, and } \\
26 \mathrm{IU} / \mathrm{mL} \text { and } 247 \text { normalized } \\
\text { neutralization titers }\left(\mathrm{NF}_{50}\right) \text { for } \\
\text { pseudovirus and live-virus } \\
\text { neutralization, respectively }\end{array}$ & \\
\hline \multirow{3}{*}{$\begin{array}{l}\text { Lau et al. } \\
\text { [8] }\end{array}$} & \multirow[t]{3}{*}{ Cohort study } & \multirow{3}{*}{$\begin{array}{l}\text { Immunity } 90 \\
\text { days after } \\
\text { infection with } \\
\text { SARS-COV-2/ } \\
\text { convalescence }\end{array}$} & \multirow[t]{3}{*}{ Human } & $\mathrm{N} / \mathrm{A}$ & \multirow{2}{*}{$\begin{array}{l}\text { The threshold for } 50 \% \\
\text { protection from re-infection } \\
\text { for PRNT } \text { and }_{50} \text { PRT } \\
1: 25.9(95 \% \mathrm{Cl} 1: 24.7-1: 27.6) \\
\text { and } 1: 8.9(95 \% \mathrm{Cl} 1: 8.6-1: 9.4) \\
\text { respectively }\end{array}$} \\
\hline & & & & \multirow{2}{*}{$\begin{array}{l}\text { Neutralizing antibody is } \\
\text { clearly one major correlate } \\
\text { of protection, but the titers } \\
\text { associated with protection from } \\
\text { re-infection are not precisely } \\
\text { defined }\end{array}$} & \\
\hline & & & & & $\begin{array}{l}50 \% \text { of patients who recover } \\
\text { from symptomatic SARS-CoV } \\
\text { would be protected from } \\
\text { re-infection for } 701 \text { days based } \\
\text { on PRNT }_{90} \text { titers or } 990 \text { days as } \\
\text { estimated by PRNT }_{50} \text { titers }\end{array}$ \\
\hline
\end{tabular}


Table 1. Correlates titer of protection against SARS-CoV-2 proposed by different study groups (continued)

\begin{tabular}{|c|c|c|c|c|c|}
\hline $\begin{array}{l}\text { Authors, } \\
\text { reference }\end{array}$ & $\begin{array}{l}\text { Type of } \\
\text { study }\end{array}$ & Design & $\begin{array}{l}\text { Subjects, } \\
\text { participants }\end{array}$ & $\begin{array}{l}\text { Methods for anti-SARS-CoV-2 } \\
\text { antibodies detection, units }\end{array}$ & $\begin{array}{l}\text { Proposed correlate titer of } \\
\text { protection (units) }\end{array}$ \\
\hline $\begin{array}{l}\text { Meschi } \\
\text { et al. [54] }\end{array}$ & $\begin{array}{l}\text { Observational } \\
\text { study }\end{array}$ & $\begin{array}{l}\text { Antibody } \\
\text { response to an } \\
\text { mRNA vaccine }\end{array}$ & $\begin{array}{l}\text { Human, } 120 \\
\text { vaccinated } \\
\text { HCW and } 94 \\
\text { previously } \\
\text { infected }\end{array}$ & $\begin{array}{l}\text { N/A } \\
\text { Quantitative anti-RBD and virus } \\
\text { microneutralization test for } \\
\text { robust ( } \geq 1: 80 \text { ) MNT titer } \\
\text { A threshold of 2,000 BAU/mL } \\
\text { is highly predictive of strong } \\
\text { MNT response in vaccinated } \\
\text { individuals and may represent } \\
\text { a good surrogate marker of a } \\
\text { protective response }\end{array}$ & $\begin{array}{l}\text { Correlation between BAU and } \\
\text { MNT titers (MNT titer }(\geq 1: 80) \\
\text { was reached at } 1,814 \text { and } \\
3,564 \mathrm{BAU} / \mathrm{mL} \text { ) }\end{array}$ \\
\hline $\begin{array}{l}\text { Bates } \\
\text { et al. [55] }\end{array}$ & Cohort study & $\begin{array}{l}\text { Vaccine/ } \\
\text { convalescence }\end{array}$ & $\begin{array}{l}\text { Human, } \\
\text { vaccinated } \\
\text { and } \\
\text { previously } \\
\text { infected }\end{array}$ & $N / A$ & $\begin{array}{l}\text { Escape of the emerging } \\
\text { SARS-CoV-2 variants from } \\
\text { neutralization by serum } \\
\text { antibodies, which may lead } \\
\text { to reduced protection from } \\
\text { re-infection or increased risk of } \\
\text { vaccine breakthrough }\end{array}$ \\
\hline $\begin{array}{l}\text { Earle } \\
\text { et al. [47] }\end{array}$ & $\begin{array}{l}\text { Statistical } \\
\text { analysis }\end{array}$ & Vaccine & Human & $\mathrm{N} / \mathrm{A}$ & $\begin{array}{l}\text { Antibody titers correlated with } \\
\text { efficacy across seven different } \\
\text { vaccines; where higher } \\
\text { titers correlated with higher } \\
\text { vaccine efficacy, despite other } \\
\text { uncontrolled variables }\end{array}$ \\
\hline $\begin{array}{l}\text { Khoury } \\
\text { et al. [10] }\end{array}$ & $\begin{array}{l}\text { Statistical } \\
\text { analysis }\end{array}$ & Vaccine & Human & $\mathrm{N} / \mathrm{A}$ & $\begin{array}{l}\text { Despite the known } \\
\text { inconsistencies between } \\
\text { studies, a comparison of } \\
\text { normalized neutralization } \\
\text { levels and vaccine efficacy } \\
\text { demonstrated a remarkably } \\
\text { strong non-linear relationship } \\
\text { between mean neutralization } \\
\text { level and the reported } \\
\text { protection across different } \\
\text { vaccines }\end{array}$ \\
\hline $\begin{array}{l}\text { Dimeglio } \\
\text { et al. [48] }\end{array}$ & Cohort study & $\begin{array}{l}\text { Vaccinated/ } \\
\text { unvaccinated/ } \\
\text { convalescence }\end{array}$ & $\begin{array}{l}\text { Humans, } \\
8758 \mathrm{HCWs}\end{array}$ & $\begin{array}{l}\text { NAb titer } \geq 256 \text { was associated } \\
\text { with full }(100 \%) \text { protection } \\
\text { ELISA-concentration of } \\
1,700 \mathrm{BAU} / \mathrm{mL} \text { and above } \\
\text { provided full protection }\end{array}$ & $\begin{array}{l}\text { The thresholds of protection } \\
\text { should be confirmed in further } \\
\text { studies on other populations. } \\
\text { Antibody's reduced neutralizing } \\
\text { capacity against new emerging } \\
\text { VOC should be tested }\end{array}$ \\
\hline $\begin{array}{l}\text { van der } \\
\text { Lubbe } \\
\text { et al. [45] }\end{array}$ & Animal model & Vaccine & $\begin{array}{l}\text { Syrian } \\
\text { hamsters }\end{array}$ & $\begin{array}{l}\text { Nab protective titer between } \\
64-128 \\
\text { ELISA } \log _{10} \text { between } 3.5-4\end{array}$ & $\begin{array}{l}\text { Hamsters were classified } \\
\text { either as infected or protected } \\
\text { from SARS-CoV-2, defined } \\
\text { as a lung viral load of either } \\
\text { above or below } 102 \text { TCID } 50 / g \text {, } \\
\text { respectively }\end{array}$ \\
\hline $\begin{array}{l}\text { Tostanoski } \\
\text { et al. [46] }\end{array}$ & Animal model & Vaccine & $\begin{array}{l}70 \text { Syrian } \\
\text { golden } \\
\text { hamsters }\end{array}$ & $\begin{array}{l}\text { RBD-specific binding } \\
\text { antibodies were assessed by } \\
\text { ELISA }\end{array}$ & $\begin{array}{l}\text { A significant correlation was } \\
\text { found between ab titer and } \\
\text { lower viral load }\end{array}$ \\
\hline $\begin{array}{l}\text { Yu et al. } \\
{[50]}\end{array}$ & Animal model & Vaccine & $\begin{array}{l}\text { Rhesus } \\
\text { macaques, } \\
\text { non-human } \\
\text { primates }\end{array}$ & Log Nab titer & $\begin{array}{l}\text { Log Nab titer above } 2.0 \\
\text { provided complete protection }\end{array}$ \\
\hline
\end{tabular}


Table 1. Correlates titer of protection against SARS-CoV-2 proposed by different study groups (continued)

\begin{tabular}{|c|c|c|c|c|c|}
\hline $\begin{array}{l}\text { Authors, } \\
\text { reference }\end{array}$ & $\begin{array}{l}\text { Type of } \\
\text { study }\end{array}$ & Design & $\begin{array}{l}\text { Subjects, } \\
\text { participants }\end{array}$ & $\begin{array}{l}\text { Methods for anti-SARS-CoV-2 } \\
\text { antibodies detection, units }\end{array}$ & $\begin{array}{l}\text { Proposed correlate titer of } \\
\text { protection (units) }\end{array}$ \\
\hline $\begin{array}{l}\text { McMahan } \\
\text { et al. [3] }\end{array}$ & Animal model & Convalescent & $\begin{array}{l}\text { Non-human } \\
\text { primates } \\
\text { ( } 31 \text { rhesus } \\
\text { macaques) }\end{array}$ & NAb titres & $\begin{array}{l}\text { NAb titers of approximately } \\
500 \text { fully protected macaques, } \\
\text { and titers of approximately } 50 \\
\text { partially protected macaques. } \\
\text { These titers should be readily } \\
\text { achievable by vaccination } \\
\text { in humans. These data } \\
\text { demonstrate that relatively } \\
\text { low NAb titers are sufficient to } \\
\text { protect against SARS-CoV-2 in } \\
\text { rhesus macaques }\end{array}$ \\
\hline $\begin{array}{l}\text { Haveri } \\
\text { et al. [56] }\end{array}$ & $\begin{array}{l}\text { Observational } \\
\text { study }\end{array}$ & Convalescense & Humans & $\mathrm{Nab}$ & $\begin{array}{l}\text { NAb against the WT virus } \\
\text { persisted in } 89 \% \text { and S-IgG } \\
\text { in } 97 \% \text { of subjects for at least } \\
13 \text { months after infection. } \\
\text { Only } 36 \% \text { had N-IgG by } 13 \\
\text { months. The mean S-lgG } \\
\text { concentrations declined from } \\
8 \text { to } 13 \text { months by less than } \\
\text { one-third; N-lgG concentrations } \\
\text { declined by two-thirds }\end{array}$ \\
\hline $\begin{array}{l}\text { Xiang } \\
\text { et al. [39] }\end{array}$ & $\begin{array}{l}\text { Observational } \\
\text { study }\end{array}$ & $\begin{array}{l}\text { Convalescent } \\
\text { COVID-19 } \\
\text { patients }\end{array}$ & Humans & Virus neutralizing $A b$ & $\begin{array}{l}\text { After one year, approximately } \\
90 \% \text { of recovered patients } \\
\text { still had detectable } \\
\text { SARS-CoV-2-specific } \\
\text { IgG antibodies against } \\
\text { nucleocapsid antigen and } \\
\text { RBD-S. Neutralizing activity } \\
\text { was detectable in } \sim 43 \% \text { of } \\
\text { patients with a reduction of } \\
\text { virus-neutralizing capacity of } \\
22.6 \% \text { to VOC }\end{array}$ \\
\hline
\end{tabular}

NC: not computed; BAL: broncho-alveolar lavage; Ab: antobodies; VE: vaccine efficacies; NF neutralization titer; N/A: not applicable; MNT: minimal neutralizing titer; WT: wild type; $\mathrm{PRNT}_{50}$ : plaque reduction neutralization at $50 \%$ neutralization endpoint; $\mathrm{PRNT}_{90}$ : plaque reduction neutralization at $90 \%$ neutralization endpoint; NS: non-significant

\section{The role of memory immune cells against SARS-CoV-2}

The authorized SARS-CoV-2 vaccines generate anti-infection neutralization antibodies. However, the underlying protective immune responses remain unknown. T follicular helper (Tfh) cells-a subset of CD4 $\mathrm{T}$ cells - are necessary for producing Nabs, and some of them [circulating Tfh (cTfh)] are examined in the blood [57]. Nevertheless, there is not much known about SARS-CoV-2 infection and mounted Tfh responses so far. It is challenging to examine lymphoid tissues in people directly. However, the cTfh or Tfh in the blood is essential for understanding Tfh reactions in germinal centers. SARS-CoV-2-specific cTfh are seen in convalescent people. Boppana et al. [58] investigated cTfh's reactions in people retrieved from COVID-19 to three critical structural proteins. They show that SARS-CoV-2-specific cTfh numbers correlate with antibody neutralizing responses [58]. Furthermore, cTfh reactions to proteins other than S protein can help Nabs development and delay the establishment of cTfh reactions in the SARS-CoV-2 infection [57].

T-cell immunity will probably play a role in SARS-CoV-2 protection by aiding the generation of Nabs. In 26 convalescent patients, Turner et al. [57]. have longitudinally investigated CD4 T cell responsiveness to SARS-CoV-2 membrane (M), nucleocapsid (N), and S structural proteins. During the first 2 months following the beginning of the illness, at least one CD4 $\mathrm{T}$ cell response was mounted by a majority (81\%). The cTfh cells [programmed cell death 1 (PD1); CXCR5 ${ }^{+} \mathrm{PD} 1^{+} \mathrm{CD} 4 \mathrm{~T}$ cell] were mountable by $48 \%$ in people. SARS-CoV-2-specific cTfh responses were observed across all antibody neutralization and S protein-specific correlation. When reviewed over time, a second convalescence, median 38 days after symptoms, cTfh responses were reported, in particular against $M$ protein, enhanced convalescence antibodies and strong cTfh responses higher than 5\%. Three and six months after the symptoms, CD4 T cell reactions decreased but 
remained at modest magnitudes. These results extend our knowledge of the cTfh-specific antigen response in SARS-CoV-2 infections, showing that cTfh may also help create Nabs, in addition to $\mathrm{S}, \mathrm{M}$, and $\mathrm{N}$ proteins, that are protein-specific, and that cTfh response formation in SARS-CoV-2 may be delayed. Late recovery lowers the amplitude of SARS-CoV-2-specific cTfh response [57].

Additionally, Turner et al. [57] demonstrated that plasma secretion of IgG and IgA aimed against the $S$ protein peaked one week after the second vaccination and decreased after three weeks. These plasma reactions preceded maximum levels of serum anti-S and Nabs for an early SARS-CoV-2 strain as well as new variations, particularly in patients previously SARS-CoV-2 infected (who produced the most robust serological responses). They have also discovered active germinal centers consisting of B cells producing antibodies against $S$ protein in each participant following vaccination by analyzing fine nose aspirates of draining axillary lymph nodes [57]. High frequencies of S-specific B cells and plasmablasts were sustained in these draining lymph nodes for at least 12 weeks following booster vaccination. Antibodies produced by these B cells mainly targeted the S protein RBD and fewer N-terminal clones or shared epitopes with human beta-CoVs S-protein OC43 or HKU1. These later cross-reactive B-cell clones reveal the origin of B-cell memory. The authors concluded that immunizations based on SARS-CoV- 2 mRNA cause a permanent germinal center $B$ reaction that generates substantial humoral immunity [57].

\section{Conclusions}

Identifying correlates of protection in support of future vaccine deployment is urgently needed for predictive models of COVID-19 immune protection. On the other hand, it would be necessary to have specific serological testing to allow those deemed immunes to rejoin the workplace when social distance restrictions are lifted. Evidence from prior new HCoVs indicates that cross-reactivity with endemic HCoVs gives little false-positive results. Antibody titers may not necessarily translate into immunity, however. Still, there is a knowledge gap in protective correlating and durability of immunity against SARS-CoV-2.

\section{Abbreviations}

BAU/mL: binding antibody units

CI: confidence interval

CoV-2: coronavirus 2

COVID-19: coronavirus disease 2019

cTfh: circulating $\mathrm{T}$ follicular helper

ELISA: enzyme-linked immunosorbent assay

Fc: fragment crystallizable region

HCoV: human coronavirus

HCWs: healthcare workers

IgG: immunoglobulin G

M: membrane

MERS: Middle East respiratory syndrome

Nabs: neutralizing antibodies

RBD: receptor-binding domain

S: spikes

SARS: severe acute respiratory syndrome

Tfh: $\mathrm{T}$ follicular helper

VNT: virus-neutralizing titer

VOC: variants of concern 


\section{Declarations}

Author contributions

YS and TV contributed conception and design of the study; DG and NI searched and organized the existing papers on the topic in a database; YS organized the table; TV crafted the figure; YS wrote the first draft of the manuscript; DG, NI, and TV wrote sections of the manuscript. All authors contributed to manuscript revision, read and approved the submitted version.

\section{Conflicts of interest}

The authors declare that they have no conflicts of interest.

Ethical approval

Not applicable.

\section{Consent to participate}

Not applicable.

\section{Consent to publication}

Not applicable.

Availability of data and materials

Not applicable.

Funding

Not applicable.

\section{Copyright}

(C) The Author(s) 2022.

\section{References}

1. COVID-19 coronavirus pandemic [Internet]. United States: Worldometers; [cited 2021 Nov 16]. Available from: https://www.worldometers.info/coronavirus/

2. Velikova TV, Kotsev SV, Georgiev DS, Batselova HM. Immunological aspects of COVID-19: what do we know? World J Biol Chem. 2020;11:14-29.

3. McMahan K, Yu J, Mercado NB, Loos C, Tostanoski LH, Chandrashekar A, et al. Correlates of protection against SARS-CoV-2 in rhesus macaques. Nature. 2021;590:630-4.

4. Walsh EE, Frenck RW Jr, Falsey AR, Kitchin N, Absalon J, Gurtman A, et al. Safety and immunogenicity of two RNA-based COVID-19 vaccine candidates. N Engl J Med. 2020;383:2439-50.

5. Manners C, Larios Bautista E, Sidoti H, Lopez OJ. Protective adaptive immunity against severe acute respiratory syndrome coronaviruses 2 (SARS-CoV-2) and implications for vaccines. Cureus. 2020;12:e8399.

6. Aleebrahim-Dehkordi E, Soveyzi F, Deravi N, Rabbani Z, Saghazadeh A, Rezaei N. Human coronaviruses SARS-CoV, MERS-CoV, and SARS-CoV-2 in children. J Pediatr Nurs. 2021;56:70-9.

7. Huang AT, Garcia-Carreras B, Hitchings MDT, Yang B, Katzelnick LC, Rattigan SM, et al. A systematic review of antibody mediated immunity to coronaviruses: kinetics, correlates of protection, and association with severity. Nat Commun. 2020;11:4704.

8. Lau EH, Hui DS, Tsang OT, Chan WH, Kwan MY, Chiu SS, et al. Long-term persistence of SARS-CoV-2 neutralizing antibody responses after infection and estimates of the duration of protection. EClinicalMedicine. 2021;41:101174.

9. Anichini G, Terrosi C, Gori Savellini G, Gandolfo C, Franchi F, Cusi MG. Neutralizing antibody response of vaccinees to SARS-CoV-2 variants. Vaccines (Basel). 2021;9:517. 
10. Khoury DS, Cromer D, Reynaldi A, Schlub TE, Wheatley AK, Juno JA, et al. Neutralizing antibody levels are highly predictive of immune protection from symptomatic SARS-CoV-2 infection. Nat Med. 2021;27:1205-11.

11. Tso EY, Tsang OT, Lam B, Ng TK, Lim W, Lai TS. Natural course of severe acute respiratory syndrome-associated coronavirus immunoglobulin after infection. J Infect Dis. 2004;190:1706-7.

12. Sui J, Li W, Murakami A, Tamin A, Matthews LJ, Wong SK, et al. Potent neutralization of severe acute respiratory syndrome (SARS) coronavirus by a human $\mathrm{mAb}$ to $\mathrm{S} 1$ protein that blocks receptor association. Proc Natl Acad Sci U S A. 2004;101:2536-41.

13. Du L, Zhao G, He Y, Guo Y, Zheng BJ, Jiang S, et al. Receptor-binding domain of SARS-CoV spike protein induces long-term protective immunity in an animal model. Vaccine. 2007;25:2832-8.

14. Guo X, Guo Z, Duan C, Chen Z, Wang G, Lu Y, et al. Long-term persistence of IgG antibodies in SARS-CoV infected healthcare workers. medRxiv [Preprint]. 2020 [cited 2021 Nov 10]. Available from: https://www. medrxiv.org/content/10.1101/2020.02.12.20021386v1

15. He Y. Immunogenicity of SARS-CoV: the receptor-binding domain of S protein is a major target of neutralizing antibodies. Adv Exp Med Biol. 2006;581:539-42.

16. Chan KH, Chan JF, Tse H, Chen H, Lau CC, Cai JP, et al. Cross-reactive antibodies in convalescent SARS patients' sera against the emerging novel human coronavirus EMC (2012) by both immunofluorescent and neutralizing antibody tests. J Infect. 2013;67:130-40.

17. Du L, Ma C, Jiang S. Antibodies induced by receptor-binding domain in spike protein of SARS-CoV do not cross-neutralize the novel human coronavirus hCoV-EMC. J Infect. 2013;67:348-50.

18. Temperton NJ, Chan PK, Simmons G, Zambon MC, Tedder RS, Takeuchi Y, et al. Longitudinally profiling neutralizing antibody response to SARS coronavirus with pseudotypes. Emerg Infect Dis. 2005;11:411-6.

19. Traggiai E, Becker S, Subbarao K, Kolesnikova L, Uematsu Y, Gismondo MR, et al. An efficient method to make human monoclonal antibodies from memory B cells: potent neutralization of SARS coronavirus. Nat Med. 2004;10:871-5.

20. Gao W, Tamin A, Soloff A, D'Aiuto L, Nwanegbo E, Robbins PD, et al. Effects of a SARS-associated coronavirus vaccine in monkeys. Lancet. 2003;362:1895-6.

21. Kobinger GP, Figueredo JM, Rowe T, Zhi Y, Gao G, Sanmiguel JC, et al. Adenovirus-based vaccine prevents pneumonia in ferrets challenged with the SARS coronavirus and stimulates robust immune responses in macaques. Vaccine. 2007;25:5220-31.

22. Liu W, Fontanet A, Zhang PH, Zhan L, Xin ZT, Baril L, et al. Two-year prospective study of the humoral immune response of patients with severe acute respiratory syndrome. J Infect Dis. 2006;193:792-5.

23. Rockx B, Donaldson E, Frieman M, Sheahan T, Corti D, Lanzavecchia A, et al. Escape from human monoclonal antibody neutralization affects in vitro and in vivo fitness of severe acute respiratory syndrome coronavirus. J Infect Dis. 2010;201:946-55.

24. Alshukairi AN, Zhao J, Al-Mozaini MA, Wang Y, Dada A, Baharoon SA, et al. Longevity of Middle East respiratory syndrome coronavirus antibody responses in humans, Saudi Arabia. Emerg Infect Dis. 2021;27:1472-6.

25. van Doremalen N, Haddock E, Feldmann F, Meade-White K, Bushmaker T, Fischer RJ, et al. A single dose of ChAdOx1 MERS provides protective immunity in rhesus macaques. Sci Adv. 2020;6:eaba8399.

26. Zhao J, Alshukairi AN, Baharoon SA, Ahmed WA, Bokhari AA, Nehdi AM, et al. Recovery from the Middle East respiratory syndrome is associated with antibody and T-cell responses. Sci Immunol. 2017;2:eaan5393.

27. Callow KA. Effect of specific humoral immunity and some non-specific factors on resistance of volunteers to respiratory coronavirus infection. J Hyg (Lond). 1985;95:173-89.

28. Callow KA, Parry HF, Sergeant M, Tyrrell DA. The time course of the immune response to experimental coronavirus infection of man. Epidemiol Infect. 1990;105:435-46. 
29. Turner JS, Kim W, Kalaidina E, Goss CW, Rauseo AM, Schmitz AJ, et al. SARS-CoV-2 infection induces long-lived bone marrow plasma cells in humans. Nature. 2021;595:421-5.

30. Tomic A, Skelly DT, Ogbe A, O'Connor D, Pace M, Adland E, et al. Divergent trajectories of antiviral memory after SARS-Cov-2 infection. Research Square [Preprint]. 2021 [cited 2021 Sep 10]. Available from: https://www.researchsquare.com/article/rs-612205/v1

31. Okba NMA, Müller MA, Li W, Wang C, GeurtsvanKessel CH, Corman VM, et al. Severe acute respiratory syndrome coronavirus 2-specific antibody responses in coronavirus disease patients. Emerg Infect Dis. 2020;26:1478-88.

32. Zohar T, Loos C, Fischinger S, Atyeo C, Wang C, Slein MD, et al. Compromised humoral functional evolution tracks with SARS-CoV-2 mortality. Cell. 2020;183:1508-19.e12.

33. Galipeau Y, Greig M, Liu G, Driedger M, Langlois MA. Humoral responses and serological assays in SARS-CoV-2 infections. Front Immunol. 2020;11:610688.

34. Zhu L, Xu X, Zhu B, Guo X, Xu K, Song C, et al. Kinetics of SARS-CoV-2 specific and neutralizing antibodies over seven months after symptom onset in COVID-19 patients. Microbiol Spectr. 2021;9:e0059021.

35. Madu IG, Roth SL, Belouzard S, Whittaker GR. Characterization of a highly conserved domain within the severe acute respiratory syndrome coronavirus spike protein S2 domain with characteristics of a viral fusion peptide. J Virol. 2009;83:7411-21.

36. Zhou P, Yuan M, Song G, Beutler N, Shaabani N, Huang D, et al. A protective broadly cross-reactive human antibody defines a conserved site of vulnerability on beta-coronavirus spikes. BioRxiv [Preprint]. 2021 [cited 2021 Nov 12]. Available from: https://www.biorxiv.org/content/10.1101/2021.03.30.437769v1

37. Feng S, Phillips DJ, White T, Sayal H, Aley PK, Bibi S, et al; Oxford COVID Vaccine Trial Group. Correlates of protection against symptomatic and asymptomatic SARS-CoV-2 infection. Nat Med. 2021;27:2032-40.

38. The use of antibody tests for SARS-COV-2 in the context of digital green certificates [Internet]. ECDC: Stockholm; c2021 [cited 2021 Nov 16]. Available from: https://www.ecdc.europa.eu/en/publicationsdata/use-antibody-tests-sars-cov-2-context-digital-green-certificates

39. Xiang T, Liang B, Fang Y, Lu S, Li S, Wang H, et al. Declining levels of neutralizing antibodies against SARS-CoV-2 in convalescent COVID-19 patients one year post symptom onset. Front Immunol. 2021;12:708523.

40. Castro Dopico X, Ols S, Loré K, Karlsson Hedestam GB. Immunity to SARS-CoV-2 induced by infection or vaccination. J Intern Med. 2022;291:32-50.

41. Koch T, Mellinghoff SC, Shamsrizi P, Addo MM, Dahlke C. Correlates of vaccine-induced protection against SARS-CoV-2. Vaccines (Basel). 2021;9:238.

42. Baum A, Ajithdoss D, Copin R, Zhou A, Lanza K, Negron N, et al. REGN-COV2 antibodies prevent and treat SARS-CoV-2 infection in rhesus macaques and hamsters. Science. 2020;370:1110-5.

43. Krammer F, Srivastava K, Alshammary H, Amoako AA, Awawda MH, Beach KF, et al. Antibody responses in seropositive persons after a single dose of SARS-CoV-2 mRNA vaccine. N Engl J Med. 2021;384:1372-4.

44. Velikova T, Georgiev T. SARS-CoV-2 vaccines and autoimmune diseases amidst the COVID-19 crisis. Rheumatol Int. 2021;41:509-18.

45. van der Lubbe JEM, Rosendahl Huber SK, Vijayan A, Dekking L, van Huizen E, Vreugdenhil J, et al. Ad26.COV2.S protects Syrian hamsters against G614 spike variant SARS-CoV-2 and does not enhance respiratory disease. NPJ Vaccines. 2021;6:39.

46. Tostanoski LH, Wegmann F, Martinot AJ, Loos C, McMahan K, Mercado NB, et al. Ad26 vaccine protects against SARS-CoV-2 severe clinical disease in hamsters. Nat Med. 2020;26:1694-700.

47. Earle KA, Ambrosino DM, Fiore-Gartland A, Goldblatt D, Gilbert PB, Siber GR, et al. Evidence for antibody as a protective correlate for COVID-19 vaccines. Vaccine. 2021;39:4423-8. 
48. Dimeglio C, Herin F, Martin-Blondel G, Miedougé M, Izopet J. Antibody titers and protection against a SARSCoV-2 infection. J Infect. 2021;[Epub ahead of print].

49. Mercado NB, Zahn R, Wegmann F, Loos C, Chandrashekar A, Yu J, et al. Single-shot Ad26 vaccine protects against SARS-CoV-2 in rhesus macaques. Nature. 2020;586:583-8.

50. Yu J, Tostanoski LH, Peter L, Mercado NB, McMahan K, Mahrokhian SH, et al. DNA vaccine protection against SARS-CoV-2 in rhesus macaques. Science. 2020;369:806-11.

51. Sui Y, Bekele Y, Berzofsky JA. Potential SARS-CoV-2 immune correlates of protection in infection and vaccine immunization. Pathogens. 2021;10:138.

52. Velikova T. Infection-acquired versus vaccine-induced immunity against COVID-19. Cent Asian J Med Hypotheses Ethics. 2021;2:29-35.

53. Corbett KS, Nason MC, Flach B, Gagne M, O' Connell S, Johnston TS, et al. Immune correlates of protection by mRNA-1273 immunization against SARS-CoV-2 infection in nonhuman primates. BioRxiv [Preprint]. 2021 [cited 2021 Nov 16]. Available from: https://www.biorxiv.org/content/ 10.1101/2021. $04.20 .440647 \mathrm{v} 2$

54. Meschi S, Matusali G, Colavita F, Lapa D, Bordi L, Puro V, et al. Predicting the protective humoral response to a SARS-CoV-2 mRNA vaccine. Clin Chem Lab Med. 2021;59:2010-8.

55. Bates TA, Leier HC, Lyski ZL, McBride SK, Coulter FJ, Weinstein JB, et al. Neutralization of SARS-CoV-2 variants by convalescent and BNT162b2 vaccinated serum. Nat Commun. 2021;12:5135.

56. Haveri A, Ekström N, Solastie A, Virta C, Österlund P, Isosaari E, et al. Persistence of neutralizing antibodies a year after SARS-CoV-2 infection in humans. Eur J Immunol. 2021;51:3202-13.

57. Turner JS, O'Halloran JA, Kalaidina E, Kim W, Schmitz AJ, Zhou JQ et al. SARS-CoV-2 mRNA vaccines induce persistent human germinal centre responses. Nature. 2021;596:109-13.

58. Boppana S, Qin K, Files JK, Russell RM, Stoltz R, Bibollet-Ruche F, et al. SARS-CoV-2-specific circulating T follicular helper cells correlate with neutralizing antibodies and increase during early convalescence. PLoS Pathog. 2021;17:e1009761. 